\title{
Low Temperature Storage and in vitro Pollen Germination of Selected Spring Wheat Accessions
}

\author{
Bahram Baninasab ${ }^{1}$, Mirko Tabori ${ }^{2}$, Junjie Yu ${ }^{3}$, Yuxue Zhang ${ }^{4}$, Xuelian Wang ${ }^{2}$, Ian Deschiffart ${ }^{2}$ \\ \& Shahrokh Khanizadeh ${ }^{2}$ \\ ${ }^{1}$ Department of Horticulture, College of Agriculture, Isfahan University of Technology, Isfahan, Iran \\ ${ }^{2}$ Ottawa Research and Development Centre, Agriculture and Agri-Food Canada, Ottawa, ON, Canada \\ ${ }^{3}$ Key Laboratory of Plant Function Genomics of Ministry of Education, Agriculture College, Yangzhou \\ University, Yangzhou, China \\ ${ }^{4}$ Key Laboratory of Crop Genetics and Physiology of Jiangsu Province, Co-Innovation Center for Modern \\ Production Technology of Grain Crops, Yangzhou University, Yangzhou, China \\ Correspondence: Shahrokh Khanizadeh, Ottawa Research and Development Centre, Agriculture and Agri-Food \\ Canada, Ottawa, ON, K1A 0C6, Canada. Tel: 1-613-759-6563. E-mail: shahrokh.khanizadeh@agr.gc.ca
}

Received: May 30, 2017 Accepted: July 8, $2017 \quad$ Online Published: August 15, 2017

doi:10.5539/jas.v9n9p1 URL: https://doi.org/10.5539/jas.v9n9p1

\begin{abstract}
The study was conducted to evaluate in vitro pollen germination of 50 spring wheat (Triticum aestivum L.) accessions at three storage temperatures $\left(23{ }^{\circ} \mathrm{C}, 5{ }^{\circ} \mathrm{C}\right.$, and $\left.-20{ }^{\circ} \mathrm{C}\right)$. Germination of the mature pollen was measured right after harvest (0 time), and 24, 48, and $72 \mathrm{~h}$ after storage (HAS). Differences in fresh pollen germination between accessions were significant and ranged from $21.15 \%$ to $1.09 \%$. Pollen germination was the lowest at $24 \mathrm{~h}$ at room temperature. The pollens of 24 wheat accessions (AAC Scotia, AW636, AW725, AW780, AW804, AW822, AW823, Brookfield, BRS Pardela, ECSW05, ECSW38, ECSW48, ECSW49, ECSW69, Hoffman, Kleos, Major, Nass, 12NQW-237, 12NQW-413, 12NQW-414, 12NQW-436, 12NQW-754, and 12BW0374) were viable after $24 \mathrm{~h}$ when they were stored at $5{ }^{\circ} \mathrm{C}$. Sub-zero temperature did not prolong pollen viability.
\end{abstract}

Keywords: low temperature storage, pollen viability, Triticum aestivum

\section{Introduction}

In breeding programs, pollen viability and germination studies are very important for assessing the amount of pollen required for controlled pollination. The protection and preservation of pollen grain viability and longevity is of great importance to plant breeders to overcome barriers to hybridization between plants and species with different flowering times or mature plants growing in different regions (Yoshiji \& Shiokawa, 1992). The viability of pollen among plant species is variable. Creeping bent grass (Agrostis stolonifera L.) pollen lost viability dramatically within the first $1.5 \mathrm{~h}$ of storage and completely lost its viability after $3 \mathrm{~h}$ of storage (Fei \& Nelson, 2003). Maize pollen lost viability after $2 \mathrm{~h}$ under field conditions (Luna et al., 2001). The viability of pollen is greatly influenced by temperature, humidity, and genotype (Koubourisa, 2009). In most species, low temperatures and low relative humidity are favourable for pollen longevity except in the Poaceae, which requires low temperatures and high relative humidity (Adhikari \& Campbell, 1998). Storage at low temperatures under low humidity has been reported to be successful in preserving Lilium species pollen (Saxena \& Saini, 1979). Adhikari and Campbell (1998) in buckwheat suggested that a high relative humidity was required to retain the viability of pollen grain.

One of the biggest problems in wheat breeding programs is genetic variation in flowering time between elite parents. Wheat breeders may overcome differences in flowering times by storing pollen of the desired male parents until pollination can be performed. There is a general idea among wheat breeders that wheat pollen is very short lived and might be a limiting factor in the economical production of hybrid seed (Fritz \& Lukaszewski, 1989). However, there are only a few reports available on optimum storage conditions for wheat pollen grain. Fritz and Lukaszewski (1989) reported that seed set in hexapoloid wheat (Triticum aestivum L.) spring cultivars decreased from $100 \%$ to less than $10 \%$ when pollination took place using pollen stored for 45 minutes. Athwal 
and Kimber (1970) reported no seed set on "Chinese Spring" wheat when pollinations were made only 5 minutes after anther dehiscence.

Pollen viability can be assessed through in vivo and in vitro germination tests, staining with nuclear and vital dyes, and analyzing the final seed set (Heslop-Harrison et al., 1984; Razora \& Zsuffa, 1986). However, among the methods used in previous studies for assessing stored pollen, in vitro pollen germination and staining have been shown to correlate well with fertile seed yield following controlled hand pollination (Sedgley et al., 1992).

The objective of the present study was to determine in vitro pollen germination of 50 spring wheat accessions at three storage temperatures and different time.

\section{Materials and Methods}

The experiment was conducted at the Ottawa Research and Development Centre greenhouse $\left(45^{\circ} 23^{\prime} 32.9^{\prime \prime} \mathrm{N}\right.$ $75^{\circ} 43^{\prime} 01.6^{\prime \prime} \mathrm{W}$ ). The greenhouse was maintained at a temperature of $18-21{ }^{\circ} \mathrm{C}$ (day and night temperature, respectively), with $16 \mathrm{~h}$ photoperiod using a light intensity of 9000 lux, between October 2016 and February 2017.

Seeds of 50 randomly selected wheat (Triticum aestivum L.) accessions collected from different breeding programs were sown in 6-inch fibre pots $(12 \mathrm{~cm}$ height $\times 13 \mathrm{~cm}$ diameter $)$ containing $600 \mathrm{~g}$ of growth media (Pro-mix PGX, Premier, Peat Ltd., Riviere-du-Loup, Quebec, Canada).

Spikes harvested at anthesis were collected and kept in a plastic bag, and then immediately carried to the laboratory. Anthers on the middle portion of the spike of each accessions were collected and placed in eppendorf tubes and stored at room temperature $\left(23^{\circ} \mathrm{C}\right), 5^{\circ} \mathrm{C}$, and $-20^{\circ} \mathrm{C}$ for $0,24,48$, or $72 \mathrm{~h}$. Prior to germination tests, the pollens that were stored at $5{ }^{\circ} \mathrm{C}$ or $-20^{\circ} \mathrm{C}$ were warmed at room temperature for $10 \mathrm{~min}$ before evaluating in vitro pollen germination. The layout was a $(50 \times 3 \times 4)$ factorial experiment in a completely randomized design with three replications.

For in vitro germination, pollen was dusted onto microscope slide with 1-2 drops of a liquid germination medium. A modified pollen germination medium based on those described by Ge et al. (2011) was used. The growth medium consisted of $0.8 \mathrm{M}$ sucrose, $1.28 \mathrm{mM}$ boric acid, and $1.27 \mathrm{mM}$ calcium nitrate. Since the appropriate temperature for wheat pollen germination was found between $21^{\circ} \mathrm{C}$ and $25^{\circ} \mathrm{C}$ (Fritz \& Lukaszewski, 1989; Cheng \& McComb, 1992) slides were incubated at room temperature. After 30 minutes, pollen germination was examined under a microscope. Pollen grains were considered as germinated when the length of the pollen tube exceeded its diameter.

The data were subjected to factorial analysis of variance (ANOVA) with accessions, storage temperature, and storage time as the main factors. Statistical analysis was performed using the SAS and means were compared using the least significant differences (LSD) test at $p=0.05$.

\section{Results and Discussion}

Pollen germination was significantly different among the tested accessions (Table 1). The results showed that the percentage of pollen germination was variable among different accessions and was less than $22 \%$ in all of them. "13NQW-754", "12NQW-436" and "ECSW48" revealed the highest pollen germination $(21.15 \%, 19.62 \%$, and $19.33 \%$, respectively), and the lowest rate was determined in "12BW0274" and "QB(2)-126-15" (1.33\% and $1.09 \%$, respectively) (Figure 1). In agreement with the present results, Cheng and McComb (1992) reported that in wheat, the in vitro condition of pollen grains gave low and variable germination with a maximum $6.8 \%$ germination. Mature wheat pollen grain has three nuclei (one vegetative and two generative nuclei) and known as trinucleate pollen (Goss, 1968). Devrnja et al. (2012) reported that compared with binucleate pollens, trinucleate pollens have a very short lifespan but germinate at a faster rate. Mulcahy and Mulcahy (1988) also reported that species with trinucleate pollen show some problems developing pollen tubes in in vitro conditions.

Storage temperature significantly influenced pollen germination (Table 1). Results of pollen germination after storage at $23{ }^{\circ} \mathrm{C}, 5{ }^{\circ} \mathrm{C}$, and $-20^{\circ} \mathrm{C}$ showed the highest pollen germination was obtained at $5{ }^{\circ} \mathrm{C}(8.95 \%)$. There were no significant differences between pollens stored at $23{ }^{\circ} \mathrm{C}$ and $-20{ }^{\circ} \mathrm{C}$ in the percentage of pollen germination (Table 2). In agreement with the present results, D’Souza (1970) reported that pollen viability in wheat was prolonged after it was stored at $2{ }^{\circ} \mathrm{C}$ to $5{ }^{\circ} \mathrm{C}$. The loss of pollen germination at a sub-zero temperature $\left(-20{ }^{\circ} \mathrm{C}\right)$ observed in the present study may be attributed to the freezing and thawing of pollen grains. Bhat et al. (2012) reported that sub-zero temperatures might have led to intracellular ice formation, cell death, and thereby loss of germination. 
Table 1. Analysis of variance for in vitro pollen germination of 50 wheat accessions, three storage temperatures, and four storage times

\begin{tabular}{llll}
\hline Source of Variance & $\mathrm{df}$ & $\mathrm{F}$ value & $\operatorname{Pr}>\mathrm{F}$ \\
\hline Accessions (A) & 49 & 86.76 & $<0.0001$ \\
Storage Temperature (T) & 2 & 8.64 & 0.0002 \\
Storage time (ST) & 3 & $11,630.8$ & $<0.0001$ \\
$\mathrm{~A} \times \mathrm{T}$ & 98 & 1.01 & 0.4441 \\
$\mathrm{~A} \times \mathrm{ST}$ & 147 & 75.28 & $<0.0001$ \\
$\mathrm{~T} \times \mathrm{ST}$ & 6 & 7.11 & $<0.0001$ \\
$\mathrm{~A} \times \mathrm{T} \times \mathrm{ST}$ & 294 & 0.84 & 0.9626 \\
Error & 1200 & & \\
\hline
\end{tabular}

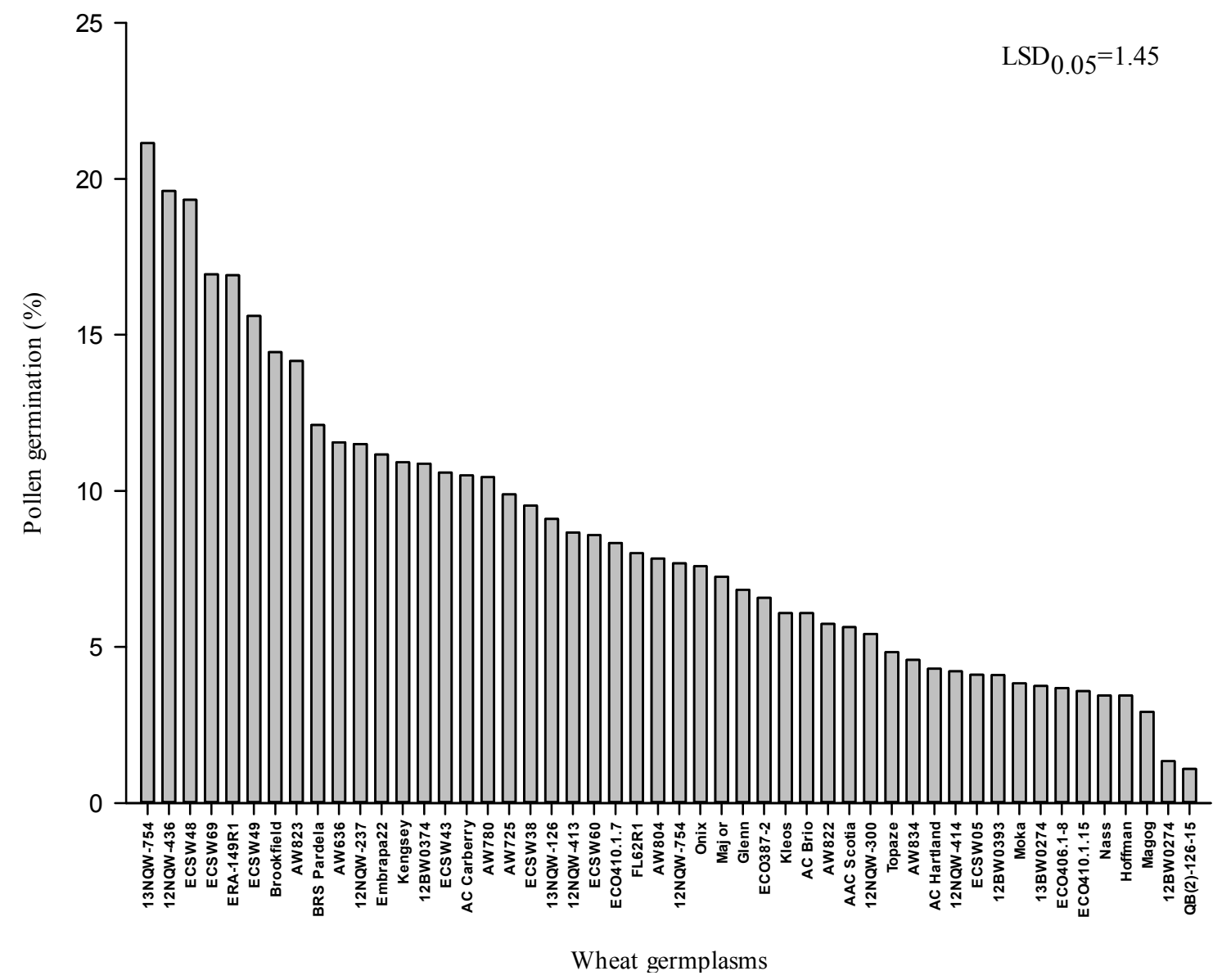

Figure 1. In vitro pollen germination of 50 wheat accessions

Pollen germination was significantly affected by storage time (Table 1). The percentage of pollen germination of all accessions under all storage temperatures rapidly decreased over the duration of the study. The results showed that pollen germination at hour 0 (fresh pollen) was $32.37 \%$; it sharply decreased at 24 hours after storage (HAS) (1.64\%), and then reached $0 \%$ at 48 and 72 HAS (Table 2). Our findings support the results of Parzies et al. (2005), who reported that in a barley genotype originating from semi-arid regions, pollen viability was reduced from more than $90 \%$ after anthesis to less than $50 \%$ within $24 \mathrm{~h}$. Our results were also consistent with previous reports on other cereal species, which showed that the pollen grains of plants such as sorghum and maize are extremely short-lived, with longevities ranging from several minutes to several hours (Luna et al., 2001; Tuinstra \& Wedel, 2000). 
Table 2. Mean of pollen germination for the factors storage temperature and storage time

\begin{tabular}{ll}
\hline Main effect & Pollen germination $(\%)$ \\
\hline Storage temperature $\left({ }^{\circ} \mathrm{C}\right)$ & \\
23 & 8.36 \\
5 & 8.95 \\
-20 & 8.24 \\
LSD & 0.35 \\
\hline Storage time $(h)$ & \\
0 & 32.37 \\
24 & 1.64 \\
48 & 0.00 \\
72 & 0.00 \\
LSD $_{0.05}$ & 0.41 \\
\hline
\end{tabular}

There was a significant interaction between genotype and storage time (Table 1). At 0 HAS, the pollen grain of all accessions was variable and "13NQW-754" showed maximum pollen germination (84.60\%), compared poor germination observed in "12BW0274" and "QB(2)-126-15" (5.33\% and 4.37\%, respectively) (data not shown). At $5{ }^{\circ} \mathrm{C}$, pollen remained viable only in less than $50 \%$ of accessions (24 accessions) within 24 HAS. Among accessions with viable pollen, "ECSW 48" showed the highest pollen germination (16\%), while the lowest germination was observed in "12 NQW-414" $(0.56 \%)$ (data not shown). There was a significant interaction between storage time and storage temperature (Table 1). Loss of pollen viability was higher in pollen grain stored at room temperature and $-20{ }^{\circ} \mathrm{C}$ where $0 \%$ pollen viability was achieved after $48 \mathrm{~h}$ storage. Results of pollen germination within $24 \mathrm{HAS}$ at $23{ }^{\circ} \mathrm{C}, 5{ }^{\circ} \mathrm{C}$, and $-20^{\circ} \mathrm{C}$ showed a significantly higher pollen germination of pollen stored at $5{ }^{\circ} \mathrm{C}(3.23 \%)$ (Figure 2).

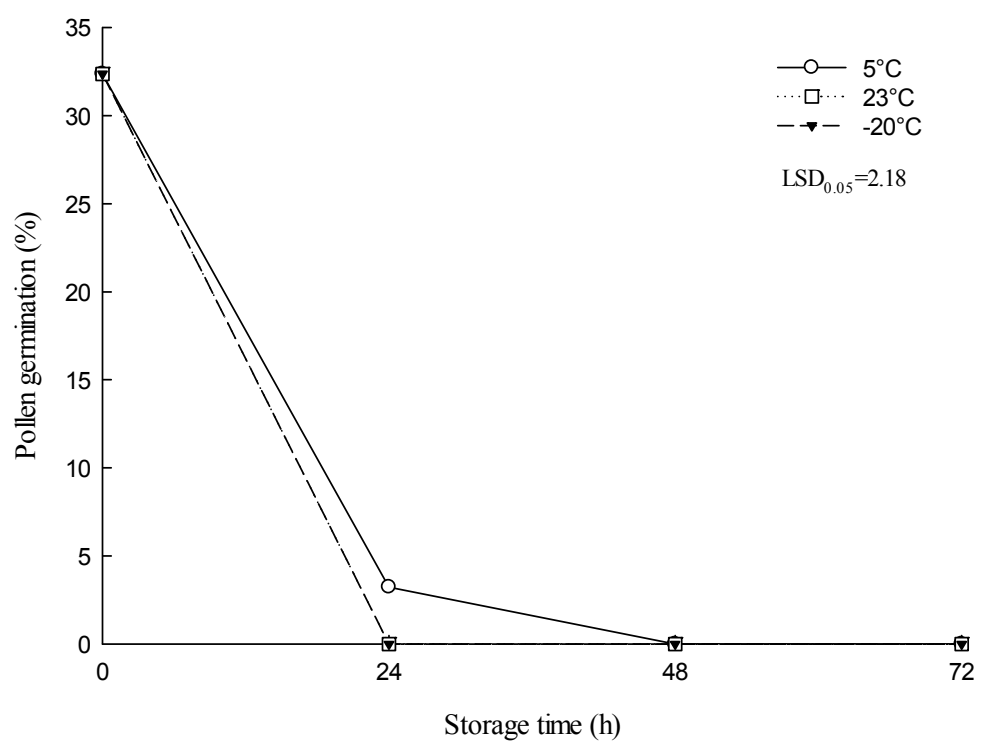

Figure 2. Effect of temperature and storage time the pollen germination

From the results of this study, it can be concluded that pollen germination was completely lost for all genotypes within $24 \mathrm{~h}$ at room temperature. Pollen of 24 wheat accessions was viable for $24 \mathrm{~h}$ when stored at $5{ }^{\circ} \mathrm{C}$. Lowering the storage temperature to $-20^{\circ} \mathrm{C}$ did not positively affect pollen germination.

\section{Acknowledgements}

This study was funded in part through Growing Forward 2 (GF2), a federal-provincial-territorial initiative with the Canadian Field Crops Research Alliance. 


\section{References}

Adhikari, K. N., \& Campbell, C. G. (1998). In vitro germination and viability of buckwheat (Fagopyrum esculentum Moench) pollen. Euphytica, 10, 87-92. https://doi.org/10.1023/A:1018393425407

Athwal, R. S., \& Kimber, G. (1970). Anther size and pollen longevity in wheat/rye addition lines. Wheat Information Service, Kyoto University, 30, 30-32.

Bhat, Z. A., Dhillon, W. S., Shafi, R. H. S., Rather, J. A., Mir, A. H., Shafi, W., ... Wani, T. A. (2012). Influence of storage temperature on viability and in vitro germination capacity of pear (Pyrus spp.) pollen. Journal of Agricultural Science, 4, 128-135. https://doi.org/10.5539/jas.v4n11p128

Cheng, C., \& McComb, J. A. (1992). In vitro germination of wheat pollen on raffinose medium. New Phytologist, 120, 459-462. https://doi.org/10.1111/j.1469-8137.1992.tb01793.x

Devrnja, N., Milojevic, J., Tubic, L. J., Zdravkovic-Korac, S., Cingel, A., \& Calic, D. (2012). Pollen morphology, viability, and germination of Tanacetum vulgare L. HortScience, 47, 440-442.

D'Souza, L. (1970). Studies on the suitability of wheat as pollen donor for cross pollination, compared with rye, Triticale and Secalotricum. Zeitschrift für Pflanzenzüchtung, 63, 246-269.

Fei, S., \& Nelson, E. (2003). Estimation of pollen viability, shedding pattern, and longevity of creeping bentgrass on artificial media. Crop Science, 43, 2177-2181. https://doi.org/10.2135/cropsci2003.2177

Fritz, S. E., \& Lukaszewski, A. J. (1989). Pollen longevity in wheat, rye and triticale. Plant Breeding, 102, $31-34$. https://doi.org/10.1111/j.1439-0523.1989.tb00311.x

Heslop-Harrison, J., Heslop-Harrison, Y., \& Shivanna, K. R. (1984). The evaluation of pollen quality and a further appraisal of the fluorochromatic (FAR) test procedure. Theoretical and Applied Genetics, 67, 367-375. https://doi.org/10.1007/BF00272876

Ge, Y., Fu, C., Bhandari, H., Bouton, J., Brummer, E. C., \& Wang, Z. Y. (2011). Pollen viability and longevity of switchgrass (Panicum virgatum L.). Crop Science, 51, 2698-2705. https://doi.org/10.2135/cropsci2011. 01.0057

Goss, J. A. (1968). Development, physiology and biochemistry of corn and wheat pollen. Botanical Review, 34, 333-358. https://doi.org/10.1007/BF02985391

Koubourisa, G. C., Metzidakis, I. T., \& Vasilakakis, M. D. (2009). Impact of temperature on olive (Olea europaea L.) pollen performance in relation to relative humidity and genotype. Environmental and Experimental Botany, 67, 209-214. https://doi.org/10.1016/j.envexpbot.2009.06.002

Luna, S. V., Figueroa, J. M., Baltazar, B. M., Gomez, R. L., Townsend, R., \& Schoper, J. B. (2001). Maize pollen longevity and distance isolation for effective pollen control. Crop Science, 41, 1551-1557. https://doi.org/ 10.2135/cropsci2001.4151551x

Mulcahy, D. L., \& Mulcahy, G. B. (1988). The effect of supplemented media in vitro on bi- and trinucleate pollen. Plant Science, 55, 213-216. https://doi.org/10.1016/0168-9452(88)90063-5

Parzies, H. K., Schnaithmann, F., \& Geiger, H. H. (2005). Pollen viability of Hordeum spp genotypes with different flowering characteristics. Euphytica, 145, 229-235. https://doi.org/10.1007/s10681-005-1167-5

Razora, O. P., \& Zsuffa, L. (1986). Pollen viability of some Populous species as indicated by in vitro germination and tetrazolium chloride staining. Canadian Journal of Botany, 64, 1086-1088. https://doi.org/10.1139/ b86-148

Sedgley, M., Harbard, J., Smith, R. M., \& Wickneswari, R. (1992). Development of hybridization techniques for Acacia mangium and Acacia auriculiformis. In L. T. Carron \& K. M. Aken (Eds.), Breeding Technologies for Tropical Acacias (Proceedings No. 37, pp. 63-69). Australian Centre for International Agricultural Research.

Saxena, H. K., \& Saini, J. P. (1979). Effect of storage on viability of Regal lily pollen grains. Indian Journal of Plant Physiology, 22, 291-271.

Tuinstra, M. R., \& Wedel, J. (2000). Estimation of pollen viability in grain sorghum. Crop Science, 40, 968-970. https://doi.org/10.2135/cropsci2000.404968x

Yoshiji, N., \& Shiokawa, Y. (1992). A study on the storage of Lilium pollen. Journal of the Japanese Society for Horticultural Science, 61, 399-403. https://doi.org/10.2503/jjshs.61.399 


\section{Copyrights}

Copyright for this article is retained by the author(s), with first publication rights granted to the journal.

This is an open-access article distributed under the terms and conditions of the Creative Commons Attribution license (http://creativecommons.org/licenses/by/4.0/). 